\title{
Predation on gray whales and prolonged feeding on submerged carcasses by transient killer whales at Unimak Island, Alaska
}

\author{
Lance G. Barrett-Lennard ${ }^{1,2, *}$, Craig O. Matkin ${ }^{3}$, John W. Durban ${ }^{4,5}$, Eva L. Saulitis ${ }^{3}$, \\ David Ellifrit $^{6}$
}

\author{
${ }^{1}$ Cetacean Research Program, Vancouver Aquarium, PO Box 3232, Vancouver, British Columbia V6B 3X8, Canada \\ ${ }^{2}$ Zoology Department, University of British Columbia, \#2370-6270 University Blvd., Vancouver, British Columbia V6B 1Z4, \\ Canada \\ ${ }^{3}$ North Gulf Oceanic Society, 3430 Main St., Suite B1, Homer, Alaska 99603, USA \\ ${ }^{4}$ National Marine Mammal Laboratory, Alaska Fisheries Science Center, National Marine Fisheries Service, \\ National Oceanic and Atmospheric Administration, 7600 Sand Point Way NE, Seattle, Washington 98115, USA \\ ${ }^{5}$ Protected Resources Division, Southwest Fisheries Science Center, National Marine Fisheries Service, \\ National Oceanic and Atmospheric Administration, 8604 La Jolla Shores Dr., La Jolla, California 92037, USA \\ ${ }^{6}$ Center for Whale Research, 355 Smugglers Cove, Friday Harbor, Washington 98250, USA
}

\begin{abstract}
As apex predators, killer whales Orcinus orca are expected to strongly influence the structure of marine communities by impacting the abundance, distribution, behavior, and evolution of their prey. Empirical assessments of these impacts are difficult, however, because killer whales are sparsely distributed, highly mobile, and difficult to observe. We present a 4 yr time series of observations of foraging and feeding behavior of $>150$ transient killer whales that aggregate annually during the northbound migration of gray whales past Unimak Island, Alaska. Most predatory attacks were on gray whale Eschrichtius robustus calves or yearlings and were quickly abandoned if calves were aggressively defended by their mothers. Attacks were conducted by groups of 3 to 4 killer whales, which attempted to drown their prey. Gray whales generally tried to move into shallow water along the shoreline when attacked; if they succeeded in reaching depths of $3 \mathrm{~m}$ or less, attacks were abandoned. Kills occurred in waters from 15 to $75 \mathrm{~m}$ deep or were moved into such areas after death. After some hours of feeding, the carcasses were usually left, but were re-visited and fed on by killer whales over several days. Carcasses or pieces of prey that floated onshore were actively consumed by brown bears Ursus arctos, and carcasses on the bottom were fed on by sleeper sharks Somniosus pacificus, apparently increasing the local density of both species.
\end{abstract}

KEY WORDS: Foraging strategy - Predatory behavior - Prey catching $\cdot$ Scavenger $\cdot$ Killer whale Gray whale $\cdot$ Brown bear $\cdot$ Sleeper shark

Resale or republication not permitted without written consent of the publisher

\section{INTRODUCTION}

Transient killer whales comprise one of 3 ecotypically distinct sympatric assemblages (transient, resident, and offshore) of Orcinus orca inhabiting the nearshore waters of the northeastern Pacific Ocean. Originally distinguished off British Columbia (Bigg 1982, Bigg et al. 1987, 1990), these assemblages are now known to ex- tend from California (Ford \& Ellis 1999) to at least as far as the central Aleutian Islands (Matkin et al. 1999b, 2007, Durban et al. 2010). Each assemblage comprises a set of 1 or more parapatric populations belonging to a well-separated monophyletic lineage (Barrett-Lennard 2000, Morin et al. 2010).

The 3 assemblages differ markedly in diet. Members of the transient assemblage are believed to feed almost 
exclusively on marine mammals, including all phocids, otariids, and phocoenids in their range and a variety of delphinids, monodontids, and mysticetes (Ford et al. 1998, Saulitis et al. 2000, Heise et al. 2003, Herman et al. 2005). Seabirds are also killed and possibly eaten on occasion, as are river and sea otters (Lutra canadensis and Enhydra lutris) (Ford et al. 1998, Vos et al. 2006). In contrast, members of the resident assemblage feed on fish, primarily salmon Oncorhynchus spp. in most areas studied (Ford et al. 1998, Saulitis et al. 2000, Herman et al. 2005), and are not known to feed on marine mammals (Matkin et al. 1999a, Ford et al. 2000, Barrett-Lennard \& Heise 2006). The third assemblage, referred to as offshore, is rarely seen and poorly studied, but its diet differs from the other assemblages (Krahn et al. 2007) and includes sharks, halibut, and possibly other fishes (Heise et al. 2003, Jones 2006, Dahlheim et al. 2008).

Transient killer whales have developed a unique set of culturally transmitted social and foraging behaviors that appear to be shaped by the behavior and distribution of their marine mammal prey. For example, they rely on stealth to a far greater extent than members of the other assemblages, reflecting differences in the predator-detection and -avoidance capabilities of their prey (Barrett-Lennard et al. 1996a, Ford \& Ellis 1999, Ford et al. 2000, Deecke et al. 2005). Foraging transients vocalize much less frequently and conspicuously than residents (Barrett-Lennard et al. 1996a, Deecke 2003, Deecke et al. 2005, Saulitis et al. 2005) and are more sparing and cryptic in their use of echolocation (Barrett-Lennard et al. 1996a). Transients have longer average dive durations than residents and often skirt along shorelines and around headlands or enter bays underwater (Morton 1990). They often use highly coordinated group hunting and attacking behaviors, in contrast to residents, which usually catch fish individually and share them afterwards (Ford \& Ellis 2006). Finally, while residents spend their lives in closed groups comprising the entire lineage of a living or recently deceased female (Bigg et al. 1990), transient groups are smaller and not strictly matrilineal (Baird \& Dill 1996, Ford \& Ellis 1999). Conducting studies that go beyond refining these generalizations about foraging and social behavior is challenging. In British Columbia, for example, approximately 250 transient killer whales range widely along $27000 \mathrm{~km}$ of coastline, making focused observational study difficult and time consuming.

Predation of other cetaceans by killer whales has been reported in many parts of the world (see Jefferson et al. 1991 and Ford \& Reeves 2008). The final stages of such attacks often occur at the surface, where they can be documented by boat-based observers, but less is known about how killer whales handle, feed on, and share or defend cetacean carcasses. Guinet et al.
(2000) noted that the time killer whales have to feed on a cetacean prey is limited by the fact that most freshly killed cetaceans sink, and unless the water is relatively shallow ( $<300$ to $400 \mathrm{~m}$ ), they fall beyond reach. This limitation of feeding time may explain reports of killer whales eating only the softest parts of large whales, the tongue and lips (e.g. Baird 2006). Guinet et al. (2000) hypothesized that killer whales could use 3 strategies to feed on large whales for longer periods: holding carcasses near the surface (requiring a coordinated group effort), driving their prey to shallow water before killing them, or partially consuming their prey alive so the prey keep themselves at the surface. Since dietary preferences and foraging behaviors have strong cultural components (Barrett-Lennard \& Heise 2006), it is likely that feeding strategies are transmitted culturally as well, and hence may differ between killer whale populations specializing on similar prey.

In the present study, we report a 4 yr series of observations of transient killer whale foraging and feeding behavior at the western end of the Alaska Peninsula near Unimak Island. All gray whales migrating between the Pacific Ocean and Bering Sea pass through this area, where they are vulnerable to predation by seasonally aggregating transient killer whales. We describe the foraging and feeding behaviors of these killer whales, including prolonged feeding on cetacean carcasses in shallow water, and contrast them with behaviors observed in the nearby eastern Aleutian Islands (Matkin et al. 2007). Finally, we present preliminary evidence of killer whales influencing community structure by provisioning bears and sharks, both high-trophic-level predators.

\section{MATERIALS AND METHODS}

Field studies were focused in the waters south and east of Unimak Island at the western end of the Alaska Peninsula (approximately $54^{\circ} 28^{\prime} \mathrm{N}, 164^{\circ} 19^{\prime} \mathrm{W}$ to $54^{\circ} 58^{\prime} \mathrm{N}, 162^{\circ} 05^{\prime} \mathrm{W}$ ) from May 16 to June 6,2003 ; May 4 to June 6, 2004; May 2 to 31, 2005; and May 2 to 31,2006 . We also make reference in the present study to observations made by 3 of the authors (L.G.B.-L., C.O.M., and D.E.) further west in the eastern Aleutian Islands, north of Umnak and Unalaska Islands (approximately $52^{\circ} 40^{\prime} \mathrm{N}, 170^{\circ} 20^{\prime} \mathrm{W}$ to $54^{\circ} 31^{\prime} \mathrm{N}, 165^{\circ} 20^{\prime} \mathrm{W}$ ) between early June and early September of 2001 through 2006 and reported in part by Matkin et al. (2007). These times and locations were chosen after consultation with local fishermen and other residents with the goal of maximizing the probability of encountering killer whales under workable weather and sea conditions. The 2 study areas are separated by Unimak Pass and are approximately $60 \mathrm{~km}$ apart. 
Field observations were conducted by a boat skipper and 2 or 3 biologists including at least one of the authors aboard 10 to $12 \mathrm{~m}$ long vessels. The teams searched for whales visually and acoustically using an underwater hydrophone for approximately $10 \mathrm{~h} \mathrm{~d}^{-1}$ at speeds of 10 to $15 \mathrm{~km} \mathrm{~h}^{-1}$. We did not run systematic survey tracks, but rather sought to maximize encounters by visiting areas where other mariners had reported killer whales or where we had seen killer whales previously. The routes taken were also affected by wind and sea conditions. The distance from which whales could be sighted from the boat varied from approximately 1 to $4 \mathrm{~km}$; acoustic detections were made at distances up to $15 \mathrm{~km}$. When a group of killer whales was located, an 'encounter' was deemed to have begun, and the vessel's position was marked on a continuous trackline recorded on the vessel's GPS. Encounters usually lasted 2 to $6 \mathrm{~h}$, depending on weather and available daylight. If a second group of killer whales was sighted and became the focus of our observing efforts, the previous encounter was considered to have ended and a new one begun. Swimming speeds of killer whales during the encounter were determined later by dividing the length of the GPS trackline by the duration of the encounter. Group sizes were determined by visual counts of individuals, which were distinguished based on naturally acquired markings and variation in pigmentation and dorsal fin shape (see Ford \& Ellis 1999).

The first priority during each encounter was to take identification photographs of as many of the killer whales present as possible while systematically moving from one subgroup to the next. The photographs were of the left side of the back and dorsal fin and were taken using an auto-focus SLR camera with a $300 \mathrm{~mm}$ lens. Images were recorded either on $35 \mathrm{~mm}$ Fuji Neopan 1600 black and white film or digitally at resolutions of 6 megapixels image ${ }^{-1}$ or greater. After processing, photographic negatives were examined under a stereomicroscope and digital images were examined on a high-resolution computer monitor. All individuals in each image were checked for matches with previously identified individuals and entered into a database, and the images were filed in a permanent collection. Individual killer whales were given reference names and one of us (D.E.) prepared a catalogue with commonly associating individuals grouped together.

When the photography was complete, skin biopsies for genetic analysis were taken from one or more killer whales using lightweight pneumatic darts (for method details see Barrett-Lennard et al. 1996b; results presented in Matkin et al. 2007). The assemblage type of killer whale groups not previously known to us was determined from mtDNA sequences as described by
Barrett-Lennard (2000) or by association of members of the group with previously identified individuals. The latter method relies on the longstanding observation that resident, transient, and offshore killer whales do not associate or intermingle (Bigg et al. 1990, Ford et al. 1998).

When the photo-identification and biopsy procedures were completed, we stayed within 100 to $500 \mathrm{~m}$ of the whales, made detailed observations of their behavior, and noted the presence of any potential prey in the area. In addition to the detailed observations, we classified the predominant behavior of the entire group using the definitions of Maniscalco et al. (2007). When predation on marine mammals was suspected but not actually seen (e.g. changes in speed or direction of travel by the whales or mobbing by gulls or eagles), we approached the position where the whales had last submerged. An observer on the bow scanned the area and retrieved prey fragments using a longhandled dip-net. The samples were stored in a sterile solution of $20 \%$ dimethyl sulfoxide in saturated saline. DNA was later extracted from the sample using Proteinase $\mathrm{K}$ digestion and phenol and chloroform purification followed by ethanol precipitation (Sambrook et al. 1989). An approximately 500 bp portion of the 5' end of the mitochondrial D-loop was PCR-amplified and the products thus obtained were sequenced using SequiTherm Excel II DNA sequencing kits (Epicentre) and electrophoresed in a $6 \%$ polyacrylamide gel on a LI-COR 4200 automated sequencer. The sequences were compared with sequences from a representative collection of northeastern Pacific marine mammal species held by one of the authors (L. G. Barrett-Lennard).

\section{RESULTS}

\section{Survey efforts and killer whale encounters}

In $102 \mathrm{~d}$ of field effort at the Unimak Island study site, we encountered killer whales that we identified genetically as transients once every $96 \mathrm{~km}$ surveyed, on average. No resident or offshore killer whales were encountered. In comparison, in $511 \mathrm{~d}$ of field effort in the adjacent eastern Aleutian study area, killer whales identified genetically as transients were encountered every $1486 \mathrm{~km}$ and killer whales genetically identified as residents every $215 \mathrm{~km}$, on average. Although average wind speeds were higher in the spring around Unimak Island than in the eastern Aleutians in the summer, the eastern side of Unimak is more sheltered from ocean swells, and sighting conditions in the 2 areas were approximately equivalent. Survey effort and encounter details are presented in Table 1, and the number of individual transients in Table 2. 
Table 1. Orcinus orca. Survey effort in the Unimak Island and eastern Aleutian study areas, 2001 to 2006 . Killer whales belonging to the offshore assemblage were encountered once, in the eastern Aleutian study area in 2003, as described in Matkin et al. (2007). na $=$ not applicable

\begin{tabular}{|c|c|c|c|c|c|c|}
\hline \multirow{3}{*}{ Year } & \multicolumn{3}{|c|}{ Unimak Island —_ } & \multirow{3}{*}{$\begin{array}{l}\text { Survey days/ } \\
\text { km traveled }\end{array}$} & \multicolumn{2}{|c|}{ - Eastern Aleutians } \\
\hline & \multirow{2}{*}{$\begin{array}{l}\text { Survey days/ } \\
\text { km traveled }\end{array}$} & \multicolumn{2}{|c|}{ No. of killer whale encounters } & & \multicolumn{2}{|c|}{ No. of killer whale encounters } \\
\hline & & Resident & Transient & & Resident & Transient \\
\hline 2001 & na & na & na & $16 / 1546$ & 13 & 1 \\
\hline 2002 & na & na & na & $188 / 12221$ & 57 & 4 \\
\hline 2003 & $18 / 1189$ & 0 & 13 & $108 / 11706$ & 49 & 5 \\
\hline 2004 & $31 / 2459$ & 0 & 32 & $130 / 12532$ & 82 & 5 \\
\hline 2005 & $26 / 2087$ & 0 & 21 & $41 / 4923$ & 6 & 5 \\
\hline 2006 & $27 / 2900$ & 0 & 24 & $28 / 3131$ & 7 & 11 \\
\hline Total & $102 / 8635$ & 0 & 90 & $511 / 46059$ & 214 & 31 \\
\hline
\end{tabular}

Table 2. Orcinus orca. Number of individual transient killer whales identified by study area and year. Total IDs: total number identified in the specified region. New IDs: number identified in the region for the first time. Overlap: cumulative count of individuals seen in both areas. na = not applicable

\begin{tabular}{|cccccc|}
\hline Year & \multicolumn{2}{c}{$\begin{array}{c}\text { Unimak Island } \\
\text { (May-Jun) }\end{array}$} & \multicolumn{2}{c|}{$\begin{array}{c}\text { Eastern Aleutians } \\
\text { (Jul-Sep) }\end{array}$} & Overlap \\
& Total IDs & New IDs & \multicolumn{2}{c}{ Total IDs New IDs } & \\
\hline 2001 & na & na & 5 & 5 & na \\
2002 & na & na & 18 & 18 & na \\
2003 & 84 & 84 & 25 & 18 & 2 \\
2004 & 75 & 30 & 22 & 16 & 4 \\
2005 & 79 & 25 & 17 & 6 & 0 \\
2006 & 87 & 15 & 18 & 6 & 5 \\
Total & & 154 & & 69 & 11 \\
\hline
\end{tabular}

Table 3. Orcinus orca. Behavioral states of transient killer whales around Unimak Island (2003-2006) and in the eastern Aleutians (2001-2004)

\begin{tabular}{|lcc|}
\hline & Unimak Island & Eastern Aleutians \\
\hline No. of encounters & 90 & 17 \\
Total duration (h) & 275 & 37 \\
Behavioral state & Percentage of observed time $(\%)$ \\
Foraging & 12 & 32 \\
Feeding & 38 & 20 \\
Traveling & 23 & 26 \\
Resting & 21 & 17 \\
Socializing & 6 & 5 \\
\hline
\end{tabular}

\section{Group sizes and behaviors}

At Unimak Island, the average $( \pm \mathrm{SD})$ group size recorded during encounters was $10.3 \pm 8.1(n=64)$, significantly greater than the average transient group size of $4.9 \pm 3.2(n=37)$ recorded in the eastern Aleutians (Student's $t$-test, $\mathrm{p}<0.001$ ). The average swimming speed at Unimak was $4.1 \pm 2.8 \mathrm{~km} \mathrm{~h}^{-1}(\mathrm{n}=66)$, significantly less than the speed of $6.5 \pm 2.6 \mathrm{~km} \mathrm{~h}^{-1}(\mathrm{n}=30)$ observed in the eastern Aleutians (Student's t-test, $\mathrm{p}<$ $0.001)$. ANOVA of the swimming speeds in each of the 2 areas showed no year-to-year differences (eastern Aleutians: $\mathrm{df}=4, F=0.50, \mathrm{p}>0.73$; Unimak Island: $\mathrm{df}=$ $3, F=1.46, \mathrm{p}>0.23)$. Group behaviors of transient killer whales observed in the Unimak and eastern Aleutian study areas are shown in Table 3. In the Unimak area, time milling near oil slicks was categorized as feeding because fragments of prey blubber and other tissue were frequently seen at the surface, but some resting and socializing also took place at these times.

\section{Observations of transient killer whales feeding, hunting, and harassing prey}

\section{Predatory attacks}

In the Unimak Island study area, we made single observations of transient killer whales briefly pursuing a group of approximately 5 Pacific white-side dolphins, chasing a single fur seal onto shore, and biting and releasing a Steller sea lion. In contrast, we saw gray whales killed 4 times and attacked or harassed on 3 other occasions. The details of these kills and harassments of gray whales were varied and are described case-by-case in Appendix 1. Key observations were as follows: (1) killer whales sometimes terminated encounters with gray whales after briefly harassing them; (2) killer whales selectively attacked young-of-theyear calves or apparent yearlings; (3) female gray whales defended their young by interposing their bodies between the killer whales and the calf and/or by vigorous tail thrashing; (4) killing was accomplished by restricting the movements of a gray whale by holding its flippers or snout and drowning it; (5) gray whales sought refuge in shallow water ( $3 \mathrm{~m}$ deep) close to 


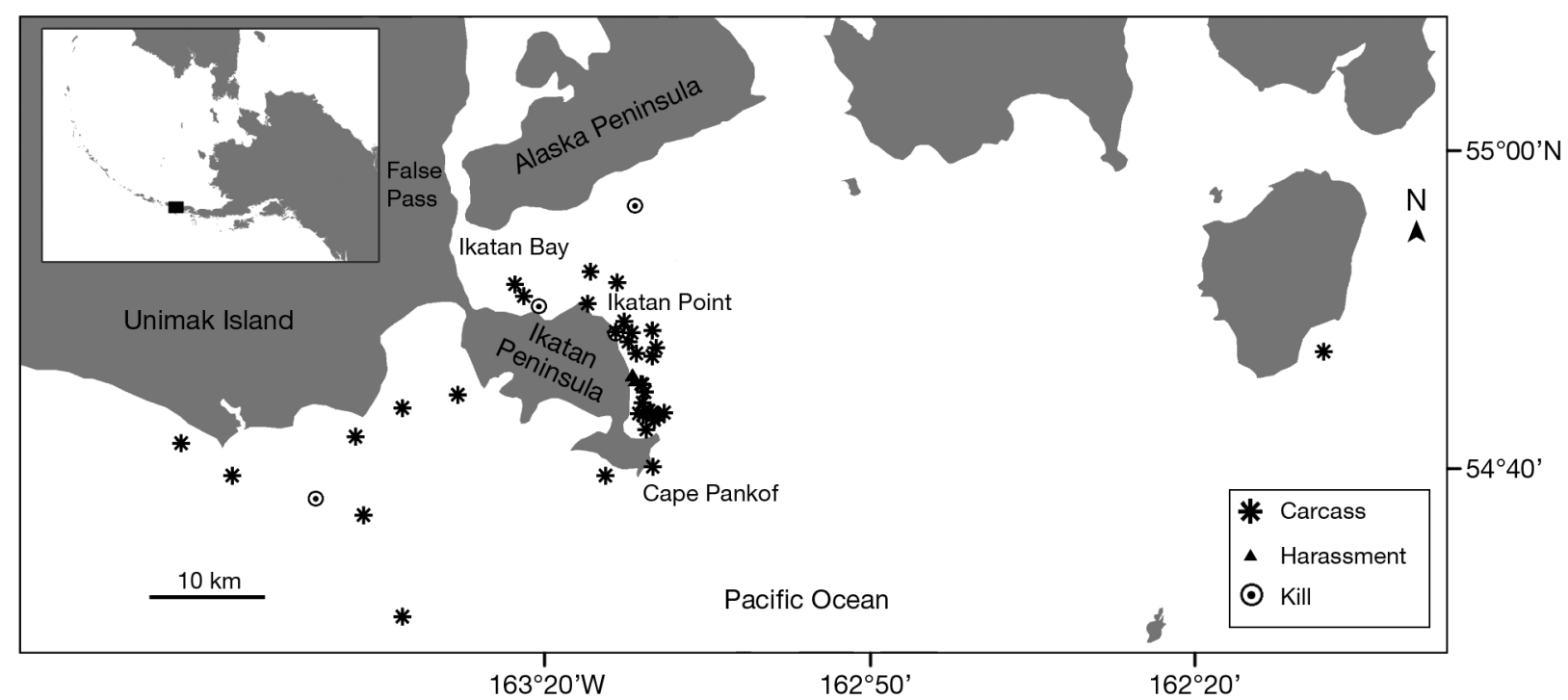

Fig. 1. Unimak Island at the western end of the Alaska Peninsula, with locations shown of gray whale harassments, kills, and carcasses marked by oil slicks

shore during attacks, and if they succeeded in reaching such an area, the attacks were abandoned; (6) killer whales actively worked to try to prevent passage to shore by ramming, biting, and dragging the gray whale by the flukes and pectoral flippers; and (7) in some cases, one or more groups of killer whales attended but did not participate in an attack pressed by another group nor did they feed on the freshly killed carcass. Other pertinent observations included: killer whales preventing a dead gray whale from sinking as they fed on it by propelling it headfirst so that it obtained lift from its flippers and flukes; a male killer whale tearing flesh from a carcass and carrying it to the vicinity of an attendant group nearby; and a calf gray whale being driven from deep offshore waters into a bay where it was killed in $15 \mathrm{~m}$ of water.

\section{Feeding on submerged gray whale carcasses}

On 37 occasions, groups of transient killer whales in the Unimak Island area were seen to maintain a stationary location for periods ranging from 1 to $6.5 \mathrm{~h}$ (Figs. 1 \& 2). These locations averaged $20 \mathrm{~m}$ in depth (range: 15 to $75 \mathrm{~m}$ ) and most were marked by conspicuous patches of surface oil extending over an estimated 100 to $500 \mathrm{~m}^{2}$. These patches (slicks) were maintained by small droplets of oil continuously rising to the surface, presumably from a marine mammal carcass on the bottom. As the surface oil drifted away from its source, it broke into smaller patches and dispersed quickly, making it easy to determine the location of fresh oil arising from below. The slicks could be easily seen with a practiced eye, particularly in choppy seas,

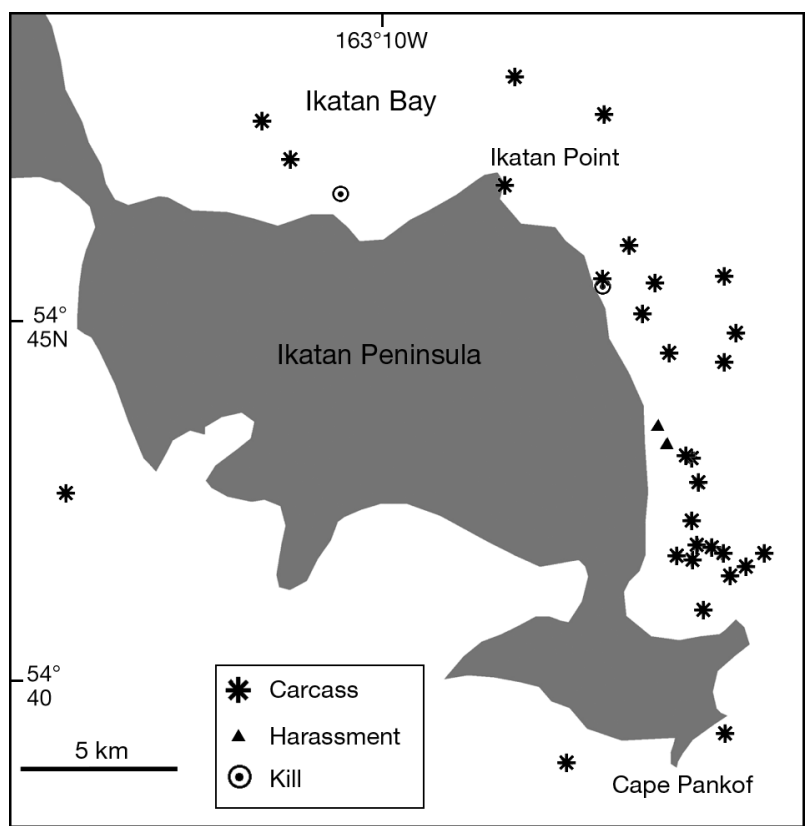

Fig. 2. Locations of gray whale kills, harassments, and carcasses marked by oil slicks in the vicinity of the Ikatan Peninsula on Unimak Island

and had a characteristic odor that we could readily detect from distances of $300 \mathrm{~m}$ or more downwind. We re-visited the sites of slicks on subsequent days whenever possible and noted that the slicks usually persisted for 2 to $3 \mathrm{~d}$, with a maximum recorded time of $5 \mathrm{~d}$. When attending a slick, the whales interspersed periods of socializing and resting with feeding bouts 
lasting 30 to $60 \mathrm{~min}$. When the whales were feeding, the oil slick increased noticeably in size and individuals often surfaced with portions of blubber and/or muscle in their mouths. These portions ranged in size from approximately $0.1 \times 0.5 \times 0.5 \mathrm{~m}$ to $0.3 \times 2.0 \times 3.0 \mathrm{~m}$. Portions of mottled gray skin, often with barnacle scars or attached barnacles, could be seen on many of the larger portions.

On 12 occasions, we were able to examine floating portions that the killer whales had abandoned. All had ragged (torn) margins and were heavily marked with parallel cuts approximately 3.5 to $5.5 \mathrm{~cm}$ apart and 3 to $4 \mathrm{~cm}$ deep, which we attributed to the teeth of killer whales. Additionally, most had 1 to 5 cleanly cut dishshaped pits averaging approximately 14 to $20 \mathrm{~cm}$ in diameter and 5 to $10 \mathrm{~cm}$ deep (Fig. 3), which we attributed to Pacific sleeper sharks Somniosus pacificus. We based this on conversations with local fishermen, who reported bites of identical appearance on halibut caught on longlines along with by-caught Pacific sleeper sharks containing similar pieces of halibut tissue. Samples were taken from fragments of floating tissue while killer whales were feeding at 27 of the slicks; all were genetically identified as gray whales. On 4 occasions, substantial portions of carcasses with one or both pectoral flippers attached were seen. In each case, the trailing edge of the flipper was marked

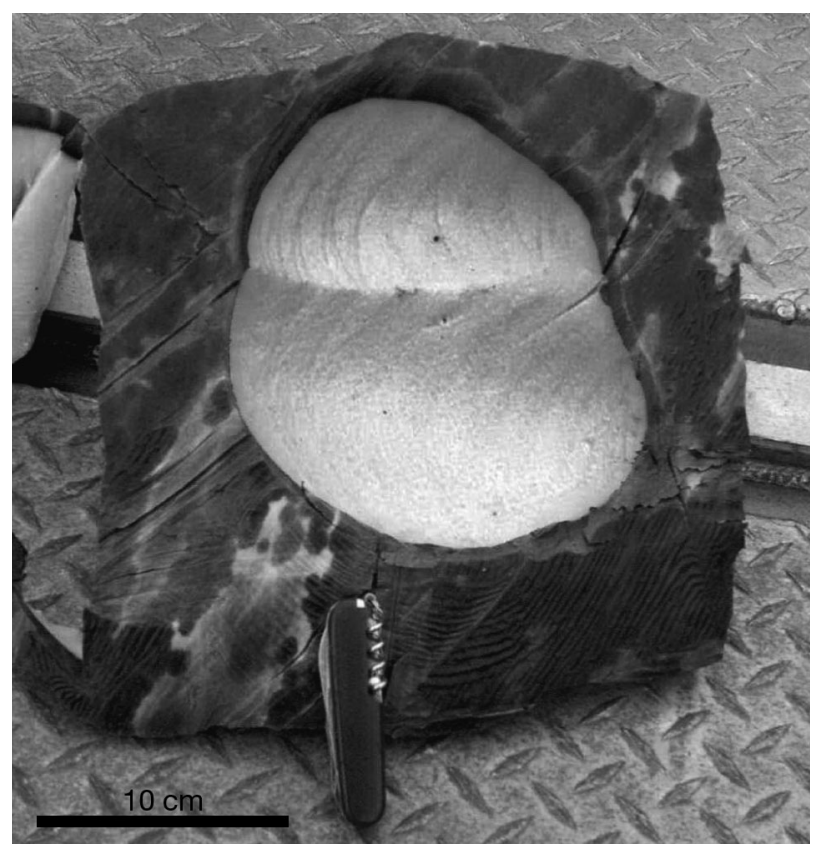

Fig. 3. Eschrichtius robustus. Portion of gray whale skin and blubber retrieved near feeding transient killer whales in the Unimak Island study area. The pit in the center is presumed to have been caused by a shark and has margins marked by fine grooves similar to those left by a serrated knife by parallel cuts apparently caused by the teeth of killer whales.

After spending from 1 to $5 \mathrm{~h}$ at the slicks, the killer whales typically left the area. Slick sites were usually re-visited by killer whales multiple times over the next few days, and we often observed groups of killer whales heading directly for a slick from $10 \mathrm{~km}$ or more away. In the cases where we knew which whale group had made the kill at a slick site, we noted that the same group returned to feed consistently on subsequent days. However, on 2 occasions we also noted groups that had not been involved in the kill at the slick site. Some single slicks slowly separated over the course of one or more feeding bouts into 2 to 3 clearly defined slicks approximately 100 to $200 \mathrm{~m}$ apart, from which we assumed the carcass on the bottom had been divided into 2 or more pieces. Whales carrying portions of blubber and flesh in their mouths often left small oil patches when they surfaced or streaks of oil if they swam just below the surface. These patches generally dissipated within 2 to $3 \mathrm{~min}$. We noted qualitatively that the oil content from these portions was highly variable and bore no obvious relationship to size, as some small portions exuded substantially more oil than much larger portions.

\section{Scavenging of gray whales killed by killer whales}

During the present study, we observed beached gray whale carcasses on 12 occasions. Alaskan brown bears Ursus arctos were frequently observed feeding on the carcasses, and precluded close further examination in all but 2 cases. Most carcasses were also attended by red foxes Vulpes vulpes. Of the 8 carcasses that could be seen clearly either from shore or with binoculars from the boat, all showed signs of attacks or harassment by killer whales, including multiple sets of fresh parallel tooth rakes on the pectoral flippers (Fig. 4), tail flukes, flanks, and throat. Several also showed evidence of partial consumption by killer whales, such as missing portions of the throat, tongue, and ventral area. One of the carcasses seen washed back into ocean within $3 \mathrm{~d}$ of being sighted; the others were sighted multiple times over a period of 2 to $3 \mathrm{wk}$.

As mentioned above ('Feeding on submerged gray whale carcasses'), most of the carcasses and portions of gray whale carcass seen floating had fresh Pacific sleeper shark bites, including one piece of blubber from a gray whale killed $4 \mathrm{~h}$ previously. Portions of floating gray whale flesh at slick sites were often attended by Northern fulmars Fulmarus glacialis and occasionally by Laysan albatross Phoebastria immutabilis, and small fragments were picked up by bald eagles Haliaeetus leucocephalus and gulls Larus spp. 


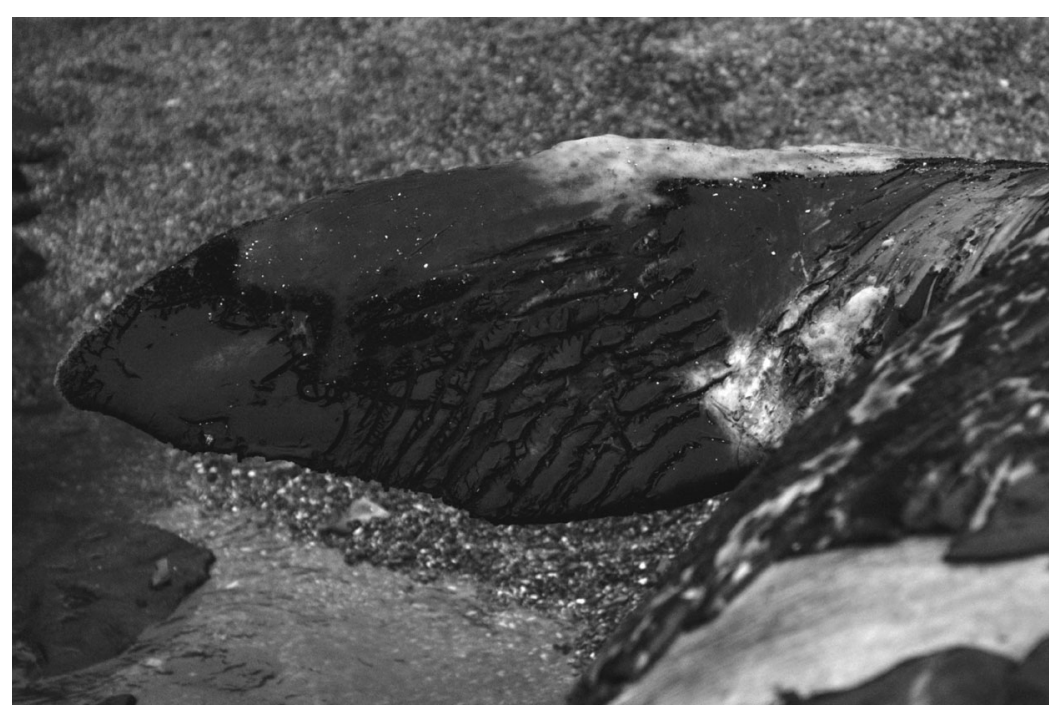

Fig. 4. Eschrichtius robustus. Pectoral flipper of a stranded gray whale that had been attacked by killer whales near False Pass, Alaska. Note the parallel cuts made by the teeth of killer whales. The other pectoral flipper, tail flukes, and lower rostrum of the whale were marked in a similar manner

migrated through this area by early summer, whereas fur seals increase in abundance as they return to breeding colonies. Two lines of reasoning suggest that differences in prey size and dispersion explain the striking differences in average group size, density, and overall number of transient killer whales observed in the 2 areas. First, successful gray whale attacks usually involve the combined efforts of several killer whales (Baldridge 1972, Goley \& Straley 1994, the present study) and provide group opportunities for prey handling, feeding, and social interactions around carcasses, whereas fur seals can be taken by a single individual (C. O. Matkin unpubl. data). Second, migrating gray whales in the Unimak Island area represent a much denser biomass of available prey than widely dispersed fur seals in the eastern Aleutians during summer.

The difference in transient killer whale travel speeds and activity bud-

\section{DISCUSSION}

\section{Differences between study areas in seasonal abundance, movements, and group sizes of killer whales}

Killer whales of all life stages are tolerant of a wide range of water temperature, salinity, and turbidity conditions, and there are no reports of populations that migrate seasonally between discrete breeding and calving areas. However, marked seasonal shifts in distribution driven by changes in the abundance, distribution, and vulnerability of prey are common (Budylenko 1981, Baird \& Dill 1995, Ford et al. 1998). Furthermore, although some killer whale populations restrict their diets to broad categories of prey (e.g. fish or marine mammals) and may specialize seasonally (e.g. Maniscalco et al. 2007), Ford et al. (1998) found no evidence that individual transients specialize on particular mammalian prey species or types. In the present study, transient killer whales in summer in the eastern Aleutians were observed to feed primarily on fur seals (Matkin et al. 2007), while in May in the adjacent Unimak Island study area, we only saw them attacking and feeding on young migrating gray whales. However, we note that these 2 areas were used mainly by different aggregations of transient killer whales, with only limited mixing of individuals (Table 2). Furthermore, gray whales have gets observed in the 2 study areas also appears to reflect differences in prey dispersion. In the Unimak area, killer whales travelled slowly along coastlines transited by a steady stream of migrating gray whales, intercepting and occasionally attacking cow-calf pairs and juveniles. In the eastern Aleutians, killer whales travelled at higher speeds as they searched much larger areas of open water for widely dispersed fur seals and minke whales and transited between distant pinniped haulouts such as Amak and Bogoslof Islands. The latter travel patterns resemble those reported for transient killer whales in British Columbia (Morton 1990, Ford et al. 1998) and Prince William Sound (Barrett-Lennard et al. 1996a, Saulitis et al. 2000), where the whales appear to make regular but short visits to widely separated pinniped haulouts. Similarly, the observation that the eastern Aleutian killer whales spent more time foraging than those around Unimak (Table 3) is consistent with the greater challenge of finding prey in the former location. Our observation that a greater percentage of time was spent feeding at the Unimak than the eastern Aleutian site might be explained by (1) greater effort being required to tear up and feed on whale carcasses than to feed on pinnipeds; (2) Unimak killer whales taking in greater quantities of food, possibly in excess of their maintenance needs; or (3) competition among group members, and hence feeding rate, being less with larger food items. 
In both the eastern Aleutian Islands and the Unimak Island study areas, we noted that the composition of groups was stable. In the long-studied west-coast transient population ranging from Washington State to SE Alaska, individual whales occasionally disperse from their natal groups (Ford \& Ellis 1999). However, these dispersal events are rare, and would likely not be detected in a 4 to 6 yr study such as that reported here. It is therefore possible that the social organization of killer whales in these 2 well-separated regions is similar. In contrast, the fact that only 11 killer whales were seen in both study areas was unexpected and suggests that there may be some ecological partitioning among transients in the region, unlike British Columbia, where Ford et al. (1998) found no evidence of partitioning.

The frequency with which we could find killer whales in the Unimak Island study area dropped off sharply each year at the end of May. Many of them moved west to Unimak Pass for most or all of June (J. W. Durban unpubl. data). A satellite tagging study showed that some also moved north into Bristol Bay or the Bering Sea (C. O. Matkin unpubl. data), perhaps following gray whales along their migration route. A small number have been re-sighted in the Unimak Island region later in the summer and 3 were photographed at the Pribilof Islands in September, where they attacked and killed a northern fur seal (J. W. Durban unpubl. data).

\section{Predation on gray whales and storing of carcasses}

Predation on gray whales has been documented many times in the past (e.g. Jefferson et al. 1991, Goley \& Straley 1994, Ford et al. 1998, Weller et al. 2002, Ford \& Reeves 2008), but the present study is the first to (1) report killer whales feeding principally or entirely on gray whales for extended periods and (2) describe killer whales leaving prey remains and later returning to feed on them. The storing or caching of prey is widespread among terrestrial vertebrates (Vander Wall 1990), but the only published report of this behavior in a marine mammal appears to be that of Kim et al. (2005), who described 2 instances of possible prey caching by Weddell seals in the Antarctic. The consistency with which we observed transient killer whales repeatedly diving in the area of oil slicks in the Unimak study area suggests that a form of food-storing behavior is common, at least during the season when gray whales are available. Food caching by most nonpredatory species is a long-term bet-hedging strategy of provisioning for periods of relative food shortage, and caches are generally hidden. In contrast, some felines, crocodilians, and other predatory species cache prey for short periods, enabling them to consume more of the prey than they can handle or digest at one time. In these cases, caches are often defended rather than hidden (Vander Wall 1990). In addition to obvious energetic advantages of acquiring more calories from a single kill, this form of food storing increases the reward-to-risk ratio of killing dangerous prey but may also expose the predator to new risks associated with defending its prey.

Killer whale groups at Unimak Island did not appear to share their freshly killed carcasses for the first few hours, even though other groups often approached and milled nearby. We did not observe overt aggression between groups near a fresh-kill site, but neither did we see affiliative social interactions or the approaching/attending groups feeding on the carcass. This is strikingly different from reports of killer whale attacks of large whales in deeper water, where small groups of killer whales joined up during or after a kill (e.g. Pitman et al. 2001). In these situations the presence of additional whales may help to prevent the carcass from sinking beyond reach and allow prolonged feeding (Guinet et al. 2000). The period during which killing groups had exclusive access to their prey was shortlived, however, because after feeding on their prey for several hours they left the carcass unattended for $24 \mathrm{~h}$ or more. While killing groups returned to their own carcasses consistently, we twice saw whales feeding at carcasses killed and left by another group. It appears that the Unimak Island transients experience some advantage to searching for new hunting prospects rather than defending a kill until the carcass is consumed, but the nature of such a benefit is unknown.

The successful predation events that we witnessed in the Unimak area all involved gray whale calves or juveniles, in keeping with reports of killer whale predation on a number of large cetacean species (Mehta et al. 2007, Ford \& Reeves 2008). Scammon (1874) noted that young whales are most vulnerable to killer whales, and Reeves et al. (2006) observed that, with the exception of minke whales, baleen whale calves and juveniles are killed most frequently. Naessig \& Lanyon (2004), Mehta et al. (2007), and Steiger et al. (2008) provide exhaustive evidence that most humpback whales that have scars from killer whale attacks received them during the first years of life. In the coastal waters of the Chukota Peninsula, Russia, 66\% of all observed predation events by killer whales involved gray whales $(\mathrm{n}=92)$, and $85 \%$ of kills were of whales <2 yr old (Melnikov \& Zagrebin 2005).

Once isolated, calf and juvenile gray whales did not appear to protect themselves by behaving aggressively towards attacking killer whales. During 2 observed predations reported here, young whales simply rolled over onto their backs and were subsequently killed. 
This apparently submissive behavior may serve to protect the gray whale's ventral area and pectoral flippers from being rammed or bitten, but Reeves et al. (2006) suggest that it may also be a form of capture myopathy. On another occasion, we saw a gray whale juvenile that was harassed by killer whales roll repeatedly around its longitudinal axis as it moved rapidly towards shore, which prevented the killer whales from maintaining a grip on its fins and flukes and allowed it to escape (details in Appendix 1). Subsequent to the observations reported in the present study, 2 of the authors (J. W. Durban and L. G. Barrett-Lennard) saw a gray whale calf use the same behavior successfully when attacked by killer whales near Unimak Island.

In keeping with accounts summarized by Jefferson et al. (1991) and Ford \& Reeves (2008), we noted the determination of most gray whales to move into very shallow water when attacked. All of the attacks we witnessed occurred in deep water, and were only close to land where the bottom sloped steeply away from the shore. If gray whales were able to reach a depth of $3 \mathrm{~m}$ or less, killer whales ended their attacks. We believe that shallow water serves as a refugium for gray whales because (1) it constrains attacking killer whales to 2 dimensions and enables gray whales to defend themselves effectively by lashing their tail flukes laterally; (2) it eliminates 1 operating dimension, thus reducing the number of killer whales that can attack simultaneously; (3) it exposes killer whales to the risk of being crushed or scraped against the bottom; and (4) it reduces the ability of killer whales to drown their prey. Live strandings of gray whales are rare and intentional stranding and subsequent return to deeper water by gray whales was observed during the present study. The ability of gray whales to maneuver safely in shallow water is unusual among mysticetes and may have evolved in response to killer whale predation. Furthermore, the risk of killer whale predation may explain why gray whales follow shorelines closely along some stretches of their migration routes.

\section{Impact of killer whales on gray whale populations}

Jefferson et al. (1991) and Ford \& Reeves (2008) summarized numerous accounts of gray whales being attacked and sometimes killed by killer whales. Most of these attacks occurred on the northbound gray whale migration and were concentrated in California near Monterey Bay and on the west coast of Vancouver Island. In both areas, most of the gray whales killed were calves or juveniles. Less is known about killer whale predation on the gray whales' primary feeding areas in the northern Bering and Chukchi Seas, although reports by Ljungblad \& Moore (1983) and Melnikov \& Zagrebin (2005) indicate that it occurs in both areas. There are also few reports of kills of gray whales on the southbound migration. This may reflect poor observing conditions due to poor weather and short days in the late fall and winter, but it is also possible that transient killer whales focus less on the species as gray whale calves become larger and stronger.

Despite the paucity of quantitative information, it is clear that killer whale predation is a significant cause of mortality for gray whale calves and a significant factor in the population dynamics of the species. It is therefore likely that killer whales have played a major role in gray whale evolution, as suggested by Ford \& Reeves (2008), and that they strongly affect learned behaviors. Along these lines, we speculate that gray whale migration routes shift over time in response to changes in transient killer whale numbers and distribution, and that gray whales behave most cryptically and follow shorelines most closely in areas where they have encountered killer whales in the past.

\section{Impact of killer whales on scavenger populations}

Beached partial and intact carcasses of gray whales killed by killer whales at Unimak Island may constitute an important food source for brown bears. The bears' emergence from hibernation coincides with the early part of the gray whale migration. Other food is scarce, as neither the spring growth of vegetation nor the return of salmon has yet begun. The densities of bears on Unimak Island (estimated at $0.1 \mathrm{~km}^{-2}$, Butler 2005) is high relative to many other coastal areas of Alaska (papers in Brown 2005 and Butler 2005) and may be partially explained by provisioning by killer whales. This provisioning may also affect the structure of bear populations, since large bears able to defend carcasses would have a substantial nutritional advantage over those unable to do so (see Gende \& Quinn 2004).

The observation of high rates of carcass depredation by sleeper sharks was unexpected, as most reported occurrences of the species are from deeper waters (e.g. Yang \& Page 1999). However, recent research by Hulbert et al. (2006) shows that sleeper sharks make daily vertical movements and commonly ascend to depths of $100 \mathrm{~m}$ or less, particularly at night, and Sigler et al. (2006) showed that the stomachs of sleeper sharks often contain marine mammal remains. We speculate that the frequent occurrence of gray whale carcasses in shallow water near Unimak Island attracts and provisions sleeper sharks every spring, resulting in greater concentrations of the species than in similar areas in the northeastern Pacific Ocean. 


\section{Impact of killer whales on ecological community structure}

There has been growing recognition in recent years that killer whales have the potential to strongly influence the abundance, distribution, behavior, and evolution of prey populations, and as such likely play central roles in determining the structure of marine communities (Estes et al. 1998, Corkeron \& Connor 1999, Springer et al. 2003, Ford \& Reeves 2008). Furthermore, their ability to efficiently locate, kill, and feed on many of their prey almost certainly depends on culturally transmitted behaviors specific to prey species, location, and context (Barrett-Lennard \& Heise 2006). The carcass-storing behavior described here relies on shallow depths around Unimak Island and provides a way for killer whales to utilize a greater proportion of prey carcasses than they would in a single feeding bout, increasing the benefit of preying on large and potentially dangerous species.

The apparent propensity of killer whales to develop and maintain specialized feeding behaviors such as those described in the present study narrows the dietary breadth of specific populations at the same time as it increases the dietary breadth of the species overall. Since the emergence of new feeding specializations almost certainly depends on diverse factors, including relative abundance of prey, complexity of behavioral innovations necessary to hunt new species efficiently, and social factors involved with modifying dietary preference, diet shifts in killer whales are inherently difficult to predict (Barrett-Lennard \& Heise 2006). This may explain why the influence of the species on ecological communities varies widely in time and space and why, in any given region, some prey species suffer heavy predation while other apparently available species are rarely, if ever, attacked.

Acknowledgements. Many people contributed to this project in important ways. We thank in particular our skippers $\mathrm{M}$. Britain, M. Ensley, and B. Laukitis; colleagues, friends, and crew members who assisted with Unimak Island field trips, including R. Andrews, H. Fearnbach, C. Guinet, P. Jonsson, S. Goulette, L. Herrick, L. Mazzuca, S. Moore, D. Power, B. Small, and S. Puddicombe; and colleagues assisting with advice, analysis, and reviews, including A. Trites, K. Noyes, and D. Sandilands. We also acknowledge logistic support from the Isanotski Corporation and funding from the Alaska SeaLife Center, the Northwest Universities Marine Mammal Research Consortium, the North Gulf Oceanic Society, and the Vancouver Aquarium Killer Whale Adoption Program. We are grateful to A. Miscampbell for help with genetic analyses and to C. Ritland for providing access to the University of British Columbia's Genetic Data Centre. Finally, we thank J. K. B. Ford and 3 anonymous referees for thoughtful and helpful reviews that greatly improved the paper. The field research reported here was authorized under US National Marine Fisheries Service permits No. 545-1488-01 and 5451761-00.

\section{LITERATURE CITED}

Baird RW (2006) Killer whales of the world: natural history and conservation. Voyageur Press, St. Paul, MN

Baird RW, Dill LM (1995) Occurrence and behaviour of transient killer whales: seasonal and pod-specific variability, foraging behaviour, and prey handling. Can J Zool 73: 1300-1311

Baird RW, Dill LM (1996) Ecological and social determinants of group size in transient killer whales. Behav Ecol 7: 408-416

Baldridge A (1972) Killer whales attack and eat a gray whale. J Mammal 53:898-900

Barrett-Lennard LG (2000) Population structure and mating patterns of killer whales (Orcinus orca) as revealed by DNA analysis. PhD thesis, University of British Columbia, Vancouver

Barrett-Lennard LG, Heise KA (2006) The natural history and ecology of killer whales. In: Estes JA, DeMaster DP, Doak DF, Williams TM, Brownell RL Jr (eds) Whales, whaling, and ocean ecosystems. University of California Press, Berkeley, CA, p 163-173

> Barrett-Lennard LG, Ford JKB, Heise KA (1996a) The mixed blessing of echolocation: differences in sonar use by fisheating and mammal-eating killer whales. Anim Behav 51: 553-565

> Barrett-Lennard LG, Smith TG, Ellis GM (1996b) A cetacean biopsy system using lightweight pneumatic darts, and its effect on the behavior of killer whales. Mar Mamm Sci 12:14-27

Bigg MA (1982) An assessment of killer whale (Orcinus orca) stocks off Vancouver Island, British Columbia. Rep Int Whal Comm 32:625-666

Bigg MA, Ellis GM, Ford JKB, Balcomb KC III (1987) Killer whales: a study of their identification, genealogy and natural history in British Columbia and Washington State. Phantom Press, Nanaimo, British Columbia

Bigg MA, Olesiuk PF, Ellis GM, Ford JKB, Balcomb KC III (1990) Social organization and genealogy of resident killer whales (Orcinus orca) in the coastal waters of British Columbia and Washington State. Rep Int Whal Comm Spec Issue 12:383-405

Brown C (ed) (2005) Brown bear management report of survey-inventory activities 1 July 2002-30 June 2004. Alaska Department of Fish and Game, Juneau, AK

Budylenko GA (1981) Distribution and some aspect of the biology of killer whale in the South Atlantic. Rep Int Whal Comm 31:523-525

Butler LB (2005) Unit 10 brown bear management report. In: Brown C (ed) Brown bear management report of surveyinventory activities 1 July 2002-30 June 2004. Alaska Department of Fish and Game, Juneau, AK, p 113-116

Corkeron PJ, Connor RC (1999) Why do baleen whales migrate? Mar Mamm Sci 15:1228-1245

Dahlheim ME, Schulman-Janiger A, Black N, Ternullo R, Ellifrit D, Balcomb KC III (2008) Eastern temperate North Pacific offshore killer whales (Orcinus orca): occurrence, movements, and insights into feeding ecology. Mar Mamm Sci 24:719-729

Deecke VB (2003) The vocal behavior of transient killer whales (Orcinus orca): communicating with costly calls. $\mathrm{PhD}$ thesis, University of St. Andrews

Deecke VB, Ford JKB, Slater PJB (2005) The vocal behavior of mammal-eating killer whales: communicating with costly calls. Anim Behav 69:395-405

> Durban J, Ellifrit D, Dahlheim M, Waite J and others (2010) Photographic mark-recapture analysis of clustered mam- 
mal-eating killer whales around the Aleutian Islands and Gulf of Alaska. Mar Biol 157:1591-1604

Estes JA, Tinker MT, Williams TM, Doak DF (1998) Killer whale predation on sea otters linking oceanic and nearshore ecosystems. Science 282:473-476

Ford JKB, Ellis GM (1999) Transients: mammal-hunting killer whales. University of British Columbia Press, Vancouver

Ford JKB, Ellis GM (2006) Selective foraging by fish-eating killer whales Orcinus orca in British Columbia. Mar Ecol Prog Ser 316:185-199

Ford JKB, Reeves RR (2008) Fight or flight: antipredator strategies in baleen whales. Mamm Rev 38:50-86

Ford JKB, Ellis GM, Barrett-Lennard LG, Morton AB, Balcomb KC (1998) Dietary specialization in two sympatric populations of killer whales (Orcinus orca) in coastal British Columbia and adjacent waters. Can J Zool 76: 1456-1471

Ford JKB, Ellis GM, Balcomb KC (2000) Killer whales: the natural history and genealogy of Orcinus orca in the waters of British Columbia and Washington, 2nd edn. University of British Columbia Press, Vancouver

Gende SM, Quinn TP (2004) The relative importance of prey density and social dominance in determining energy intake by bears feeding on Pacific salmon. Can J Zool 82:75-85

Goley PD, Straley JM (1994) Attack on gray whales (Eschrichtius robustus) in Monterey Bay, California, by killer whales Orcinus orca previously identified in Glacier Bay, Alaska. Can J Zool 72:1528-1530

> Guinet C, Barrett-Lennard LG, Loyer B (2000) Co-ordinated attack behavior and prey sharing by killer whales at Crozet Archipelago: strategies for feeding on negatively buoyant prey. Mar Mamm Sci 16:829-834

Heise K, Barrett-Lennard LG, Saulitis E, Matkin CO, Bain D (2003) Examining the evidence for killer whale predation on Steller sea lions in British Columbia and Alaska. Aquat Mamm 29:325-334

Herman DP, Burrows DG, Wade PR, Durban JW and others (2005) Feeding ecology of eastern North Pacific killer whales Orcinus orca from fatty acid, stable isotope, and organochlorine analyses of blubber biopsies. Mar Ecol Prog Ser 302:275-291

Hulbert LB, Sigler MF, Lunsford CR (2006) Depth and movement behavior of the Pacific sleeper shark in the northeast Pacific. J Fish Biol 69:406-425

Jefferson TA, Stacey PJ, Baird RW (1991) A review of killer whale interactions with other marine mammals; predation to co-existence. Mamm Rev 21:151-180

> Jones I (2006) A northeast Pacific offshore killer whale (Orcinus orca) feeding on a Pacific halibut (Hippoglossus stenolepis). Mar Mamm Sci 22:198-200

Kim SL, Conlan K, Malone DP, Lewis CV (2005) Possible food caching and defence in the Weddell seal: observations from McMurdo Sound, Antarctica. Antarct Sci 17:71-72

Krahn MM, Herman DP, Matkin CO, Durban JW and others (2007) Use of chemical tracers in assessing the diet and foraging regions of eastern North Pacific killer whales. Mar Environ Res 63:91-114

Ljungblad DK, Moore SE (1983) Killer whales (Orcinus orca) chasing gray whales (Eschrichtius robustus) in the northern Bering Sea. Arctic 36:361-364

Maniscalco JM, Matkin CO, Maldinini D, Calkins DG, Atkinson S (2007) Assessing killer whale predation on Steller sea lions from field observations in Kenai Fjords, Alaska. Mar Mamm Sci 23:306-321

Matkin CO, Ellis G, Olesiuk P, Saulitis E (1999a) Association patterns and inferred genealogies of resident killer whales, Orcinus orca, in Prince William Sound, Alaska. Fish Bull 97:900-919
Matkin CO, Ellis GM, Saulitis EL, Barrett-Lennard LG, Matkin DR (1999b) Killer whales of southern Alaska. North Gulf Oceanic Society, Homer, AK

Matkin CO, Barrett-Lennard LG, Yurk H, Ellifrit DK, Trites AW (2007) Ecotypic variation and predatory behavior of killer whales (Orcinus orca) in the eastern Aleutian Islands, Alaska. Fish Bull 105:74-87

Mehta AV, Allen JM, Constantine R, Garrigue C and others (2007) Baleen whales are not important as prey for killer whales Orcinus orca in high-latitude regions. Mar Ecol Prog Ser 348:297-307

> Melnikov VV, Zagrebin IA (2005) Killer whale predation in coastal waters of the Chukotka Peninsula. Mar Mamm Sci 21:550-556

Morin PA, Archer FI, Foote AD, Vilstrup J and others (2010) Complete mitochondrial genome analysis of killer whales (Orcinus orca) indicates multiple species. Genome Res 20: 908-916

Morton AB (1990) A quantitative comparison of the behavior of resident and transient forms of killer whales off the central BC coast. Rep Int Whal Comm Spec Issue 12:245-248

Naessig PJ, Lanyon JM (2004) Levels and probable origin of predatory scarring on humpback whales (Megaptera novaeangliae) in east Australian waters. Wildl Res 31: $163-170$

Pitman RL, Ballance LT, Mesnick SL, Chivers SJ (2001) Killer whale predation on sperm whales: observations and implications. Mar Mamm Sci 17:494-507

Reeves RR, Berger J, Clapham PJ (2006) Killer whales as predators of large baleen whales and sperm whales. In: Estes JA, DeMaster DP, Doak DF, Williams TM, Brownell RL Jr (eds) Whales, whaling, and ocean ecosystems. University of California Press, Berkeley, CA, p 174-187

Sambrook J, Fritsch EF, Maniatis T (1989) Molecular cloning: a laboratory manual. Cold Spring Harbor, New York, NY

> Saulitis E, Matkin C, Barrett-Lennard L, Heise K, Ellis G (2000) Foraging strategies of sympatric killer whale (Orcinus orca) populations in Prince William Sound, Alaska. Mar Mamm Sci 16:94-109

Saulitis EL, Matkin CO, Fay FH (2005) Vocal repertoire and acoustic behavior of the isolated AT1 killer whale subpopulation in southern Alaska. Can J Zool 83:1015-1029

Scammon CM (1874) The marine mammals of the northwestern coast of North America. John H. Carmany \& Co, San Francisco, CA (reprinted in 1968 by Dover, New York, NY)

Sigler MF, Hulbert LB, Lunsford CR, Thompson NH, Burek K, O'Corry-Crowe G, Hirons AC (2006) Diet of Pacific sleeper shark, a potential Steller sea lion predator, in the north-east Pacific Ocean. J Fish Biol 69:392-405

Springer AM, Estes JA, van Vliet GB, Williams TM and others (2003) Sequential megafaunal collapse in the North Pacific Ocean: an ongoing legacy of industrial whaling? Proc Natl Acad Sci USA 100:12223-12228

Steiger GH, Calambokidis J, Straley JM, Herman LM and others (2008) Geographic variation in killer whale attacks on humpback whales in the North Pacific: implications for predation pressure. Endang Species Res 4:247-256

Vander Wall SB (1990) Food hoarding in animals. University of Chicago Press, Chicago, IL

Vos DJ, Quakenbush LT, Mahoney BA (2006) Documentation of sea otters and birds as prey for killer whales. Mar Mamm Sci 22:201-205

Weller DW, Burdin AM, Wursig B, Taylor BL, Brownell RL Jr (2002) The western gray whale: a review of past exploitation, current status and potential threats. J Cetacean Res Manag 4:7-12

Yang MS, Page BN (1999) Diet of Pacific sleeper shark, Somniosus pacificus, in the Gulf of Alaska. Fish Bull 97:406-409 
Appendix 1. Detailed observations of transient killer whales Orcinus orca hunting and harassing gray whales Eschrichtius robustus

May 5, 2004. Four or five killer whales were sighted $3.5 \mathrm{~km}$ west of Ikatan Peninsula in approximately $36 \mathrm{~m}$ of water. The whales were highly excited, darting back and forth erratically in one area; one breached near the boat. An adult killer whale then surfaced, grasping the snout of a gray whale calf in its jaws. The calf wrenched itself free, but another killer whale immediately grasped it again in the same manner. The 2 killer whales held the calf with its blowhole inverted for several minutes until it released a mass of bubbles, stopped moving, and slowly submerged, apparently dead. It was not seen again, and the encounter ended shortly thereafter due to the onset of darkness.

May 10, 2004. A group of 8 killer whales was seen travelling very slowly in a tight resting formation $200 \mathrm{~m}$ off the east side of the Ikatan Peninsula, heading north. After $3 \mathrm{~h}$ of this behavior, they encountered a southbound gray whale, which they approached rapidly and surfaced close to. The gray whale immediately changed course towards shore and rolled on its back. The killer whales did not continue to press the attack, and resumed their previous behavior while the gray whale remained tight against the shore in shallow water.

May 21, 2004. A group of 8 killer whales was seen $3.5 \mathrm{~km}$ off the east side of the Ikatan Peninsula, swimming slowly $\left(3.5 \mathrm{~km} \mathrm{~h}^{-1}\right)$ to the northeast, paralleling the shoreline. After approximately $2 \mathrm{~h}$, we sighted a second group of 8 killer whales approximately $3.5 \mathrm{~km}$ ahead, swimming rapidly to the northeast. At this point the whales we were following immediately increased their speed to approximately $18 \mathrm{~km}$ $\mathrm{h}^{-1}$ in an apparent attempt to join the others. The distant group of whales appeared to be chasing or driving a small whale in a westerly direction, towards Ikatan Bay. We lost sight of both groups of killer whales for about 15 min as they rounded a headland and entered Ikatan Bay. When we resighted them, the 2 groups were in close proximity, milling in $15 \mathrm{~m}$ of water near the shoreline. After about $15 \mathrm{~min}$, an apparently dead gray whale calf was briefly pushed to the surface by 2 killer whales and over the next 30 min, a thin sheen of oil formed on the surface of the water. We deployed a hydrophone at this point and heard the killer whales calling loudly and frequently. The 2 killer groups remained separated by approximately 50 to $100 \mathrm{~m}$, with one resting continuously at the surface while the other dove repeatedly at a fixed location. About $30 \mathrm{~min}$ after sighting the dead gray whale calf, we heard characteristic Pacific white-sided dolphin calls and within several minutes, 5 dolphins approached the killer whales, swam briefly among them, and then departed. We did not observe any reaction to the dolphins on the part of the whales. After an hour of milling in the same location in the oil sheen, the resting whales departed in a southeasterly direction while the active group of killer whales moved slowly $2 \mathrm{~km}$ northeast towards the other side of Ikatan Bay and once again stopped to mill in $15 \mathrm{~m}$ of water. Immediately a second sheen of oil formed and we briefly saw the tail flukes of a gray whale calf, suggesting that the killer whales had moved part or all of the carcass from the first location to the second. The killer whales continued to mill in place and we left the scene $2 \mathrm{~h}$ later.

May 16, 2005. Six killer whales (1 adult male, 2 females or subadult males, and 3 calves and juveniles) were sighted $10 \mathrm{~m}$ from an adult and a calf gray whale that were in approximately $5 \mathrm{~m}$ of water $25 \mathrm{~m}$ from a gravel beach in a small cove. The gray whales appeared agitated and lifted their heads from the water for several minutes, at which point the killer whales rushed in and one slid upside down over the back of the calf gray whale. The adult gray whale lashed out with lateral movements of its tail, appearing to strike at least one of the killer whales, while the calf remained between it and the beach. At this point, the killer whales moved out of the cove and milled $250 \mathrm{~m}$ from the gray whales. After $1 \mathrm{~h}$ the gray whales moved slowly north from the cove and were joined by 2 Steller sea lions that swam and breathed synchronously with them. The killer whales re-approached and swam several meters behind or offshore of them, but were not seen to make contact. After $30 \mathrm{~min}$, the gray whales stopped in a patch of kelp in the mouth of a stream. The killer whales remained nearby for $20 \mathrm{~min}$ and then departed the area, stopping to feed over the next few hours on 3 carcasses marked by light oil slicks.

May 6, 2006. Two adult females and one subadult male killer whale were sighted off the east side of Ikatan Peninsula travelling at approximately $5 \mathrm{~km} \mathrm{~h}^{-1}$ in a northerly direction $250 \mathrm{~m}$ offshore in approximately $15 \mathrm{~m}$ of water. Shortly after the start of the encounter they turned to the south in the direction of a lone gray whale yearling traveling southbound across the mouth of East Anchor Cove. When the distance had closed to 200-300 $\mathrm{m}$, the killer whales accelerated underwater and surfaced beside the gray whale, with one of them sliding up on its back. At first, the gray whale seemed to offer little resistance other than rolling on its back and holding its pectoral flippers against its body as the female killer whales bit its flippers and flukes multiple times while the male forced it backwards while pushing on its head. After approximately $1 \mathrm{~min}$, the gray whale began to struggle more actively and pressed towards shore. The killer whales tried to block it with their bodies, alternately forcing its head into the air several times and then grasping its flukes and flippers and dragging it a body length or more further away from shore. The gray whale then began to roll repeatedly around its longitudinal axis, which prevented the killer whales from maintaining a grip on its fins and flukes and allowed it to progress towards shore. When it was approximately $100 \mathrm{~m}$ from shore, it broke free of its attackers and moved in rapidly until it was within $10 \mathrm{~m}$ of a gravel beach. The killer whales milled near the scene for $10 \mathrm{~min}$ and then moved off several kilometers to the south, joining up with 8 other killer whales to feed on a submerged gray whale carcass from a previous kill. The gray whale had bloody cuts in its pectoral flipper and flukes, but did not appear to be mortally injured, and was seen to be resting near the beach as we left to follow the killer whales.

May 8, 2006. Four killer whales comprising 1 adult male, 2 adult females, and 1 juvenile were seen surfacing with violent exhalations and vigorous surface splashing next to an adult gray whale in a $30 \mathrm{~m}$ depth, $50 \mathrm{~m}$ from the shore of Ikatan Peninsula. After several minutes the killer whales swam approximately $100 \mathrm{~m}$ from the gray whale, which moved closer inshore and traveled off to the south. We then saw that the killer whales were dragging a gray whale calf that appeared to have been freshly killed. The killer whales remained in the same location for $2.5 \mathrm{~h}$ before showing signs of active feeding, at which point they opened the abdominal cavity. Chunks of floating blubber and intestines appeared on the surface and a large oil slick formed over the next half hour. While continuing to feed, the killer whales resumed moving slowly and dragged the calf 
Appendix 1 (continued)

approximately $3 \mathrm{~km}$ parallel to shore eventually, stopping in $24 \mathrm{~m}$ of water and resuming feeding.

The same 4 whales plus 4 additional adult females and another juvenile were seen feeding at 2 slicks $50 \mathrm{~m}$ apart in the same location the following morning. Although they passed within $50 \mathrm{~m}$ of each other at times, the 2 groups were not seen mixing. On the second day after the kill, a third group, comprising 2 adult females, 2 juveniles, a calf, and an adult male not seen on either of the previous days were seen feeding at a slick at the same location, while the group of 5 seen on May 9 fed at a slick $150 \mathrm{~m}$ away. Whales within the third group were observed pulling on and biting a floating piece of gray whale skin and blubber estimated to be $1.5 \mathrm{~m}$ square and $12 \mathrm{~cm}$ thick. It had torn margins, numerous punctures of the type produced by killer whale teeth, and pits resembling shark bites as described in the next section. The group of 4 killer whales from May 8 was seen $300 \mathrm{~m}$ from the other groups briefly, but was not seen feeding and moved off slowly to the south. No interactions or direct contact between the 3 groups was seen.

May 15, 2006. A group of 4 female and/or subadult male killer whales was observed following an adult and calf gray whale south along a beach on the east side of Ikatan Peninsula. Each time the killer whales surfaced they were close behind the gray whales but oriented in the opposite direction. At one point we observed a juvenile Steller sea lion just ahead of the killer whales. One killer whale accelerated rapidly and grabbed the sea lion in its jaws, releasing it a few seconds later. The sea lion was then struck by the tail flukes of another killer whale. No blood or oil sheen was seen and shortly afterwards a sea lion of the same general description hauled out on nearby rocks. The killer whales paused momentarily and then resumed following the gray whales, which hugged the shoreline very closely and continued to swim south rapidly. Just before they reached a large shallow cove, the larger gray whale pushed the calf, which was being closely pressed by the killer whales, up into a rocky shallow area where it grounded partially, and blocked its return to deeper water with its snout. With its body exposed, we could see that it had suffered deep parallel lacerations, presumably from the teeth of killer whales, on its flukes and rostrum. In the process of pushing the calf into the shallows, the adult became partially grounded and struggled off the rocks by slashing it flukes and undulating its body. During this period, the killer whales moved several hundred meters offshore. Ten minutes later the calf wriggled off the rocks, and it and the adult travelled off slowly along the shoreline, through East Anchor Cove and west along the south shore of Unimak Island. The killer whales followed them for several kilometers, and then turned back to East Anchor Cove, where they fed upon a submerged carcass marked by a large oil sheen.

May 26, 2006. At 16:49 h, approximately 25 killer whales were observed milling $9 \mathrm{~km}$ south of Unimak Island in $105 \mathrm{~m}$ of water. The whales were in 4 groups, each separated from its nearest neighbor by approximately $0.5 \mathrm{~km}$. An adult male (WT014) that had been observed associating temporarily with several different social groups in previous field seasons was by himself. One group referred to as the WT08 group comprising 3 females and a calf that had always been seen together in the past began diving in one spot. The dive durations were shorter than those of the surrounding groups
(90 s compared to 4-5 min, estimated). Each whale exhaled explosively on surfacing and took 4 to 5 rapid breaths before diving again. No more than 2 of the 4 whales were on the surface at any given time. After observing this behavior for 30 min, we saw that the WT08 group was holding an intact gray whale approximately $10 \mathrm{~m}$ long about $8 \mathrm{~m}$ below the surface. It was not apparent whether it was alive or dead, but it did not appear to be struggling. The killer whales did not appear to be feeding on it, but were grasping its pectoral flippers and snout with their jaws and propelling it slowly through the water in a shore-wise direction. Its pectoral flippers were stretched perpendicular to its body and appeared to be providing lift as it glided along at $3.2 \mathrm{~km} \mathrm{~h}^{-1}$. At one point it was unattended briefly and immediately began to angle steeply downwards, head first. After a few seconds, one of the females swam underneath, grasped the throat or lower jaw, and propelled it back up to a depth of 8 to $10 \mathrm{~m}$. Approximately 10 min after the gray whale was first seen, the male WT014 joined the active group of killer whales. It was not possible to determine whether he assisted in propelling/holding up the gray whale, and although he was seen within $10 \mathrm{~m}$ of other members of the group and began to dive and breathe in a similar manner, he was not seen intermingling with them.

The whales in the other 3 groups remained within several hundred meters of the group with the gray whale and milled quietly on the surface but did not take part in the activity. We caught sight of the gray whale several times over the next 20 min still being propelled in the manner described above. Then 3 members of the WT08 group surfaced. One rolled upside down while the other 2 pulled at an object that it was holding in its mouth. The nearest attendant group then approached to a distance of approximately $50 \mathrm{~m}$ and the other 2 attendant groups approached to the same distance a few minutes later. When this occurred, the WT08 whales tail-lobbed and the attendants moved 200 to $300 \mathrm{~m}$ away. Several minutes later, the WT08 whales pushed the carcass of the gray whale to the surface briefly and appeared to tear blubber from it. WT014 swam in the direction of one of the attendant groups with an approximately $1 \times 1 \times 0.3 \mathrm{~m}$ piece of blubber and flesh in his mouth, returning 1 min later with his mouth empty. The carcass was not seen again. The WT08 whales continued to dive repeatedly in the same spot, now marked by a large oil slick, until 18:55 h, while the attendant groups continued to mill nearby. The depth at this location was approximately 40 fathoms (73 m). At 19:00 $\mathrm{h}$, the active group began to rest at the surface and briefly intermingled with one of the attendant groups. One of the other attendant groups breached and tail-slapped for several minutes and then traveled away from the scene. We left the scene from 19:45 to 20:50 h, by which time the killer whales had left the area, which was marked by a slick. One $0.75 \times 0.5 \mathrm{~m}$ (estimated) piece of gray whale blubber was floating nearby. It had torn margins, 2 round, cleanly cut bowl-shaped pits $15 \mathrm{~cm}$ in diameter and $10 \mathrm{~cm}$ deep, resembling shark bites, and its outer surface was extensively scored with parallel cuts approximately $4 \mathrm{~cm}$ apart. When we returned to the same location the following day at 16:00 $\mathrm{h}$, one of the attendant groups was milling near the still-visible slick. The WT08 group arrived at the scene at 18:40 h and both groups milled about $200 \mathrm{~m}$ apart until 20:00 h, when they joined up and traveled slowly away from the site. 